\title{
The Migration of the Population in the South Albania: The Case of Gjirokastra Region
}

\section{Associate Professor Valbona Duri}

\author{
Geography Department, Faculty of Education and Social Sciences, "Eqrem Çabej” University, Gjirokastër
} Email address: bongjeo@yahoo.com

\section{Doi:10.5901/ajis.2016.v5n3s1p214}

\section{Abstract}

In Albania, after the year of 1990 (referred to as the transition), the society is facing with the new social phenomena in shape, but especially in the content. Such phenomena (by different researchers), are also observed in countries that have been in the same socio-economic system as our country (Eastern Europe). The emigration seems clear becomes determinant component of demographic regime in Albania country, because of political instability, economic and social difficulty, high level of unemployment, opening of the country with the world etc. This situation provoked and stimulated a great movement in our population in the 1990s. The study of the emigration dynamic has been very intensive in this part of east Europe. The international migration (especially to Greece), is one of the main impact factor to all socio demo-economic evolution in Gjirokastra region. This research is focused on statistical evidences and analyses of the international migration from Gjirokastra region, after 1990: factors, dimensions, directions, motifs and typology of migrations (causes, distances, individual or familiar, etc.), consequences etc. International migration has been an illegal phenomenon, especially at the beginning. For a better evidence of this phenomena, it is seen and taken under researches and analyses in three dimensions: time (periods of time) and in space that is a more complex in form and content (seen according to communes and villages) and structural of the population (age, gender, ethnic group, education level and settlement). The research will be accompanied by some conclusions and suggestions, at the end. This region has been characterized by a deficit populating evolution, first of all, because of the migration phenomena.

Keywords: international migration, motives, typology, district, consequence.

\section{Introduction}

In the early 1990, Albanian society faced with new social phenomena, which have been noticed even in countries that took the same political and socio-economic direction like the ones in Eastern Europe. One of these phenomena was related to the immigration of Albanians, that although occurred early in our population and brought new features after 1990.

In the early 1990s, Albania found itself in a deep economic crisis with parameters that indicated the existence of a failing economy, making it difficult to fulfil the needs of its population. Political instability, difficult economic situation, high unemployment level etc. provoked and stimulated migration waves in our population in the 1990s (Dumani 1995). This immigration in our country since 1990 especially in the area part of this research study has made the phenomenon more complex and typical, influencing many aspects in demographic and socio-economic structure. The general scheme of immigration factors and external triggers can be summarized in many factors such are: economic, political, historical, etc.

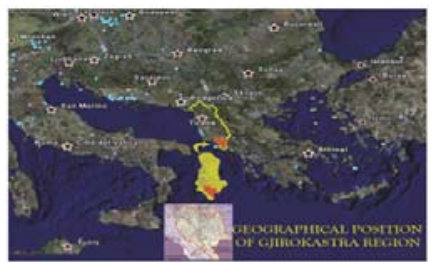

\section{Picture 1.}

Immigration started as a protest against the former communist system (the embassy phenomenon), but seems to be an economic necessity and a way to freedom (King, 2003). Transition from a centralized economy to a market based 
economy was accompanied by major economic and social difficulties (as the planned economy or market economy, lacking of confidence and insecurity for today and tomorrow). Such a situation served as the starting point for the creation and strengthening of thought to leave abroad, aspiring for a better life for themselves and their families. Examination of the dynamics of the immigration shows that in the early years it has been intense. As such, it served as a buffer in the deep discrepancy (inherited) between high surplus of natural population and limited employment opportunities.

Based on the research conducted in this context it turns out that for most of the villages in the region, in Gjirokastra and Permet, this process started at the beginning of 1991 when it encountered the greatest influx of immigrants to Greece. This process continued reaching another peak in 1997. After the events of 1997 which resulted in the total collapse of the state, a lack of peace and insecurity occurred in the country which gave rise to a massive leaving of people.

Immigration has been continuous reaching so high levels during the first years of 90s and after this period it has had a decrease. Despite later have not been tracks of massive exodus such were those of 1990, 1991 and 1997, the immigration never stopped.

According to the statistics of hosting countries immigration structure is evident the fact that round $84.0 \%$ of immigrants are settled in Greece. The reason is the geographic proximity, illegal possibilities to cross the border etc and after it moving to the Western European countries or far elsewhere taking the feature of a far immigration.

Immigration has been an illegal phenomenon and for a detailed study it became necessary to do a survey and data assessment taken from it.

\section{The Dimensions of Immigration}

Statistics show that immigration phenomenon involved some important parts of population of the region. According to INSTAT during the period 1989-2001, migrants that left the country consist in $11.0 \%$ of population in 1989, while immigrants consist in $25.3 \%$ of population in our region in 1989. According to the assessment of the survey's data, situation result to be really critical. After 1990 , round $50 \%$ of population and $45.4 \%$ of families in 1989 . It has a negative migrating rate for the mountainous communes of the region (with small surface of agricultural land round 0.27 ha/inhabitants, with problems in infrastructure etc).

The most affected communes who have a negative migratory balance are: Buz (-46.3\%), Lopes, Kurvelesh Suke, Deshnice, etc, known as mountainous areas (with limited agricultural land 12:27 hackers, and problematic infrastructure, etc.).

After 1990, from the district of Gjirokastra has immigrated $55.7 \%$ of its total population and about $40.0 \%$ of families, while in Permet District has immigrated 42.6\% of the population in 1989 and $44.2 \%$ of families in 1989.

Assessment of survey data show that in Tepelenë District, population is involved more in internal migration toward the metropolis areas such are Tiranës, Sarandës, Vlorës etc.

This phenomenon is noticed have high levels in those areas of the region where are present ethnic and cultural minorities of Greek and Vlahos population.

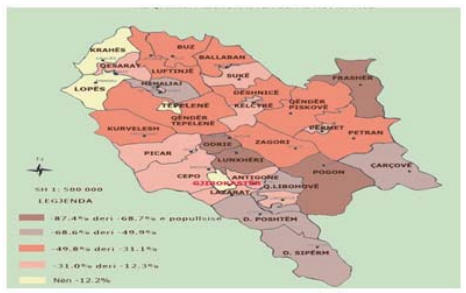

Picture 2. Migration by comunes

Referring to the immigration reasons is made evident the following:

- Economic \& Social. It is known that economic factors were migrating and primary phenomena and results comparatively with other factors. Unemployment large scale, insufficient income, the desire for a better life constitutes a brainstorm for migration. Assessments in this overview highlight that: $39.0 \%$ of the population has immigrated as the result of unemployment; $20.0 \%$ due to low income $16.0 \%$ have immigrated to secure a 
better future and $24.0 \%$ as the result of economic uncertainty. Among other factors we can mention family reunion, education etc.

= According to organising way immigration play a small role in rapport to spontaneous and illegal which are more present nowadays.

= According to duration, in the territory that is part of this research study are noticed Immigrat that aim to last for a long time where most of immigrants are living abroad for more than 20 years. Present are the temporary immigration and seasonal ones as phenomena faced in villages pretty close to Greek border. Such movements are due to agricultural processes in the neighbouring country. Weekly movements are another type of immigration when people move out of the settlements at the begining of the week to Greek villages on the other side of the border being involved in construction sector and returning back home during weekend.

- Immigrant strukture. In the analyses of immigration a great importance shows its structure according to the population age, gender, education level, settlements etc.

- Age structure of immigrants result to belong to a young age group of $15-45$ years old.

Consisting in $69.0 \%$, immigrants. This is quite clear having in consideration the immigration has a selective feature (select the labour force age group). Young people have more tendencies to immigrate since the physical capital is decreased by aging. Meanwhile is known the fact that elderly have close relation with land, family and environment where they live. The following situation was that of increasing age average population in 38 years old and decreasing of active population 15-34 years old in $46.1 \%(2001)^{1}$ from $64.7 \%(1989)$ of general number of population.
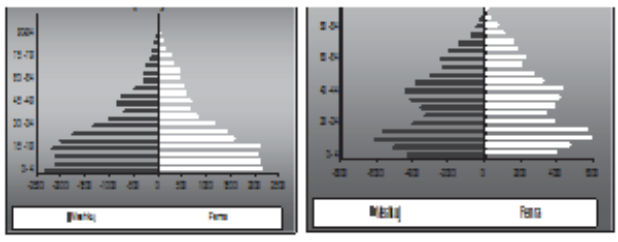

Picture 3. Age structure

- According to the gender, male immigrants consist in $50.0 \%$ of those who left the country toward $46.4 \%$ female immigrants.

Table no1. Immigration according to gender(\%)

\begin{tabular}{|l|c|c|c|c|c|c|c|c|}
\hline \multirow{3}{*}{$\begin{array}{c}\text { Years } \\
\text { Units }\end{array}$} & \multicolumn{2}{|c|}{ '89-'94 } & \multicolumn{2}{c|}{ '94-'99 } & \multicolumn{2}{c|}{ '99-'04 } & \multicolumn{2}{c|}{ '89-'04 } \\
\cline { 2 - 9 } & \multicolumn{2}{|c|}{$\mathrm{NM}^{2}$} & \multicolumn{2}{c|}{ NM } & \multicolumn{2}{c|}{ NM } & \multicolumn{2}{c|}{ NM } \\
\cline { 2 - 9 } & $\mathrm{M}$ & $\mathrm{F}$ & $\mathrm{M}$ & $\mathrm{F}$ & $\mathrm{M}$ & $\mathrm{F}$ & $\mathrm{M}$ & $\mathrm{F}$ \\
\hline Region & -43.5 & -56.5 & -59.4 & -40.6 & 53.0 & -47.0 & -52.6 & -47.4 \\
\hline Urban area & 57.4 & 42.6 & 60.0 & 40.0 & -52.2 & -47.8 & 59.5 & 40.5 \\
\hline Rural area & -52.5 & -47.5 & -56.0 & -44.0 & -51.2 & -48.8 & -53.7 & -46.3 \\
\hline
\end{tabular}

Statistics show more mobility of men compared to women both inside and outside the region. The low mobility of women is related to the immigration reasons that women are somewhat different, due to different social norms that affect them. However, gender differences have been narrowing. As a result of selective immigration feature coefficient of masculinity for the age group $20-24$ was decreased with $9.2 \%$ in $1989 .{ }^{3}$

$=$ According to education level $26.0 \%$ of immigrants have completed primary and 8 years system of education, $53.0 \%$ have completed high school education $21.0 \%$ have completed university education.

\footnotetext{
1 Data processing of Census in 1989 and 2001

2 Neto Migration

${ }^{3}$ Data processing of Census in 1989 and 2001
} 
A special attention deserve the immigration phenomenon of intellectual elite that differently from the massive immigration have involved young ages under 40 years old and many of them with families. These kind of movements decided in advance from their part and they do not have attention to come back home are considered as sustainable immigration.

= Referring to civil status and numerical part of the family it is evident a small difference between the individual immigration and family immigration. Round $32.0 \%$ of the general number is consisted in families with $4-5$ members followed from the families with up to 3 members that consist in $10.0 \%$.

$=$ Assessment of survey data showed that rural population has more tendency to be involved in immigration movement than the urban population. Immigration coefficent in villages result to be $29.1 \%$ compered to $15.6 \%$ in the city.

- According to the ethnicity more tendencies to immigrate have Greek minority and Vlahos minority and among them the latest one seem to have a higher tendency to immigrate this population have had circumstances that deprived them from integration in economic, social political and cultural life of the country.

The most wrong perception but the most common one is the point of view of immigration as a derivate of non efficient macro economic situation and the thought that immigration can be eliminated when the economy will be improved. Immigration based on its feature is a non stoppable phenomenon of human evolution. In such context introduction with it, studying of such phenomenon is really important in order to formulate proper social- economical policies that are necessary for the sustainable development.

\section{References}

Aspekte të strukturës dhe shtrirjes gjeografike të popullsisë në vendin tonë. Studime gjeografike 2 Tiranë, 1987.

Doka Dhimitër Zhvillime socio-ekonomike dhe rajonale të Shqipërisë gjatë periudhës së tranzicionit Potsdam-Gjermani, 2005.

Gërdeshi, Ilir. Mara, Hekuran. Dhimitri, Rolanda. Krisafi, Ksenofon (1999), Emigrimi i Elitës intelektuale nga Shqipëria gjatë periudhës së tranzicionit.

INSTAT Popullsia e Shqipërisë në 2001.Rezultatet e rregjistrimit të popullsisë dhe Banesave.

Laçi S. Gjeografia humane e Shqipërisë Tiranë,2005.

Misja V. Veisiu Y. Bërxholi A. Popullsia e Shqipërisë ,Tiranë, 1987.

Misja, Vladimir (1993), Aspekte te emigracionit nderkombetar ne Shqiperi, Raport studimi, Fakulteti i Ekonomise.

Strategjia e qarkut Gjirokaster, 2005

Vleresime nga anketeimi mbi emigrimin ne qarkun Gjirokaster. 